\title{
The Limitations of Citadinité in Late Ottoman Jerusalem
}

\author{
Louis Fishman
}

This chapter problematizes the notion that the political realities introduced following the 1908 Young Turk Revolution augmented a sustainable sense of harmony among the different communities in Ottoman Jerusalem. In fact, it will argue that the revolution perhaps even hindered the forging of an urban community or an idealistic type of citadinité. It does not aim to disprove that relations between communities existed within the urban arena of Jerusalem. However, it will question the extent of these relations and will set out to show how new barriers between the different communities were created as a result of political events in Istanbul and, in particular, in Palestine.

During the late Ottoman times, relations between neighbors from different religious and ethnic communities in Jerusalem can be defined as exhibiting a type of citadinité. Despite Ottoman structural divisions, which divided religious communities along sectarian lines, Muslims, Christians, and Jews interacted with one another in markets and public arenas. While it is not possible to define how widespread such interactions were, some of these communities also shared the same neighborhood. According to Michelle Campos, "deep ties [existed] between Old City Muslims, Christians, and Jewish families and neighbors across religious lines - sharing a courtyard, visiting each other on religious holidays, engaging in business partnerships ... Muslim girls learned Judeo-Spanish from their Sephardi Jewish neighbors; Christian and Jewish musicians performed at Muslim weddings and holidays."

Menachem Klein, in his recent book, goes to great lengths to document the relations between neighbors from the Jewish and Arab (Muslim and Christian) communities. According to Klein,

The unit of local identity, beyond the family and clan, was the neighborhood, or more correctly, the residential compound surrounding a common yard. While the Jews were in the majority in Jerusalem by the end

1 Michelle Campos, Ottoman Brothers: Muslims, Christians, and Jews in Early Twentieth-Century Palestine (Stanford: Stanford University Press, 2011), 18.

(C) LOUIS FISHMAN, 2018 | DOI:10.1163/9789004375741_032

This is an open access chapter distributed under the terms of the prevailing CC-BY-NC-ND License at the time of publication. 
of the nineteenth century, most of the housing was owned by Arabs. Jews lived among Arabs, and more Jews rented homes and apartments from Arabs than vice-versa. ${ }^{2}$

Furthermore, Salim Tamari, in his reading of the memoirs of Wasif Jawhariyyeh, ${ }^{3}$ paints a picture of close social ties in the daily lives of Jews and Arabs. His work serves to challenge the perception of Jerusalem as a city defined solely by bitter sectarian divisions. According to Tamari:

In [Jawhariyyeh's] rendition of daily life in the alleys of the Old City, we are struck by the weakness of this conception in two respects: one suggests that there was no clear delineation between neighborhood and religion; we see a substantial intermixing of religious groups in each quarter. The boundaries of habitat, furthermore, were the mahallat, the neighborhood network of social demarcations within which a substantial amount of communal solidarity is exhibited. Such cohesiveness was clearly articulated in periodic visitations and sharing of ceremonials, including weddings and funerals, but also active participation in religious festivities. These solidarities undermined the fixity of the confessional system from a premodern (perhaps even primordial) network of affinities. ${ }^{4}$

With the proliferation of public spaces in late nineteenth-century Jerusalem, new instances of citadinité transformed neighborhood relations. ${ }^{5}$ One of these spaces emerged in the new commercial center that lined Jaffa Road, connecting the Old City with the new neighborhoods situated outside the city's walls, which became home to the municipality in 1896. According to Abigail Jacobson, "this area was a mixed urban locale that served social, economic, and administrative functions for all of the city's inhabitants, as well as for its visitors. It was where people interacted and communicated." ${ }^{\text {Th }}$ This vibrant urban environment served both government and commercial needs, while drawing

2 Menachem Klein, Lives in Common: Arabs and Jews in Jerusalem, Jaffa, and Hebron (Oxford: Oxford University Press, 2014), 36.

3 Salim Tamari, “Jerusalem's Ottoman Modernity: The Times and Lives of Wasif Jawhariyyeh," in Jerusalem Quarterly, no. 9 (2000).

4 Tamari, "Jerusalem's Ottoman Modernity," 8.

5 Abigail Jacobson, From Empire to Empire: Jerusalem between Ottoman and British Rule (Syracuse: Syracuse University Press, 2011).

6 Ibid., 56 . 
the different ethnicities and religions together into a successful microexperiment of a modern city.

The above example reminds us that the activities of Ottoman institutions, such as recruitment to the Ottoman army, also led mixed groups to converge together in these very urban spaces. In September 1910, we see how Christians and Jews joined in a mutual day of celebration on the day they were drafted into the Ottoman army. The day started with an official ceremony held at Jerusalem's military headquarters. Army officials such as 'Abd al-Rahman, the Ottoman military attaché in Jerusalem, gave speeches. From there, the recruits were led to the train station by an Ottoman marching band, followed by families and friends from all the communities bidding them farewell at the train station, or remaining as onlookers. ${ }^{7}$ Such ceremonial events, which were prevalent in other Ottoman cities, ${ }^{8}$ allow us to capture a glimpse of a unique expression of citadinite that was inherently connected to the Ottoman period. This would disappear during the days of British rule. ${ }^{9}$ In fact, this picture is quite unique to the last years of the Ottoman Empire, since it was only after the revolution that conscription to the army became mandatory for Christians and Jews. Importantly, this did not only include the drafting of Sephardim, but that of Ashkenazim as well.

While there are numerous examples demonstrating forms of citadinité within the Hebrew press, it is important to highlight that "mixing of groups" did not only involve the mixing of Arabs with Sephardic Jews, but also with Ashkenazi Jews, including Zionists. ${ }^{10}$ These gatherings might seem surprising given that after the 1908 revolution, and leading up to World War I, Jews

Lemire looks at how the official opening of the hydraulic canals, in addition to other cases focusing on infrastructure, were also commemorated by "all the inhabitants of the city." See Vincent Lemire, Jerusalem 19oo: The Holy City in the Age of Possibilities (Chicago: University of Chicago Press, 2017), 4.

8 In her book, Sibel Zandi-Sayek describes how official ceremonies in Izmir drew crowds from its city's diverse communities together to take part in different communal events. See Sibel Zandi-Sayek, Ottoman Izmir: The Rise of a Cosmopolitan Port, 1840-1880 (Minneapolis: University of Minnesota Press, 2011), 154.

$9 \quad \mathrm{Ha}$-Or, September 21, 1910, 3; Ha-Herut, September 21, 1910, 3. In her record of the official farewell ceremony, Campos notes that the newspaper not only recognized the Jewish recruits by name, but also those who received a pardon by paying the bedel tax, in what she described as a form of humiliation. See Campos, Ottoman Brothers, 156.

10 For a unique look at relations between the influential Ashkenazi immigrant, Eliezer Ben-Yehuda, and the Palestinian Muslim notable and politician Ruhi al-Khalidi, see Jonathan Gribetz, Defining Neighbors: Religion, Race, and the Early Zionist-Arab Encounter (Princeton: Princeton University Press, 2014). 
and Arabs became more entrenched in conflict. ${ }^{11}$ An example of such a gathering was a ceremony held in the Jewish colony of Petah Tikvah to welcome the Ottoman governor, Muhdi Bey, who was on an official visit. Joining him in his entourage to the agricultural settlement was the kaimakam, Fahri Bey, the mayor of Jerusalem, Hussein Effendi Al-Husayni, and the well-known Jewish notable Albert Antébi. The Zionist representative, Arthur Ruppin, and other members of the Jewish Yishuv were also present. The newspaper Ha-Herut reported that the city was decorated with Ottoman flags and the governor was welcomed to the city by Jews and Arabs on horseback. ${ }^{2}$ The day included speeches given at the local synagogue; the Ottoman governor opted to give his speech in French, which was the dominant language among the Sephardic elite. For example, Antébi, despite being often described as the prototype Ottoman Jew, seems to have been more comfortable in French than in Ottoman Turkish. ${ }^{13}$

The fascinating portraits of citadinité within Jerusalem and in the other cities of Palestine, brought alive in works and sources, are congruent with other Ottoman cities during the late nineteenth and early twentieth centuries, where a mixing of the empire's different ethnic and religious communities began to transform the urban arena. These changes may have occurred as a direct result of the political changes within the empire during the nineteenth century, when the Ottoman state (Devlet-i 'Ośäaniye) transformed into a modern empire as the Ottoman administration strengthened Istanbul's central powers vis-à-vis the provinces. During the years of the Tanzimat (1839-76), notions of citizenship began to emerge along with a modern sense of patriotism for the vatan, the homeland, and the introduction of modern universities, newspapers, and tax reforms. These reforms also aimed to create a system of equality between all the empire's subjects, through measures such as abolishing the non-Muslim poll tax, the cizye. Nevertheless, the millet system, which allowed each community to govern its internal affairs, creating divisions between the

11 In my upcoming book, Claiming the Homeland:Jews and Arabs in Late Ottoman Palestine, 1908-1914 (tentative title), I lay out how the 1908 revolution stood as point of departure when both communities became entrenched in conflict and set out to make "claim" of their homeland. This played out both in Palestine and in Istanbul.

12 Ha-Herut, August 8, 1912.

13 Fishman, Claiming the Homeland; In one document, Antébi preferred to address the central government in Istanbul in French and not in Ottoman Turkish, unlike his Jerusalem Arab counterpart, Raghib al-Nashashibi, who in the same document addresses the government in Turkish. Ottoman State Archives (воA), DH.UмVM 1332.M.22; December, 21 1913 . 
different religious groups, remained intact in some form or another, despite radically changing in context following the 1908 revolution.

One of the direct outcomes of the Tanzimat era, that led to the promulgation of a constitution by Abdülhamid II, which was suspended until the Young Turks reinstated it in 1908, was the blurring of rigid divisions between the different ethnic and religious groups, allowing Ottoman urban citizens to cross the invisible borders that existed between the different communities. For example, during the last decades of the empire, we know that Muslims, Christians, and Jews began to study together in schools such as Galatasaray and Istanbul's renowned law school, the Hukūk Mektebi. Tramways in the major cities began to transport members of one community through the streets of the other. While Jerusalem's tramway was not established in the late Ottoman era (indeed it was only completed a few years ago), there was a plan during the last years of Ottoman rule to connect Jerusalem with the outlying areas, finally reaching Bethlehem, which would certainly have served all the communities in a similar fashion to those in Istanbul and other Ottoman cities. ${ }^{14} \mathrm{In}$ Jerusalem too, even though it was uncommon, Muslims also studied at Jewish schools, such as the two Jerusalem MPs in the postrevolutionary Ottoman parliament, Said al-Husseini and Ruhi al-Khalidi, who both studied for some time at Jerusalem's Alliance Israélite Universelle. ${ }^{15}$ While there seem to be fewer cases of Jews studying at Arab schools, a young immigrant from Russia, Moshe Sharet (né Moshe Shertok) studied briefly at an Arab school. This is probably where he picked up the fine Arabic skills we see in his letters written in the language, which were sent to his brother in Palestine while he served in the Ottoman army in Syria during World War I. ${ }^{16}$ Of course, the cases of Arabs attending Jewish institutions, and vice versa, serve as brilliant examples of citadinité. In schools and other institutions, the two groups interacted on a daily basis. However, the mixing of students and intellectuals does not seem to have produced a form of camaraderie which could have created strong bonds and joint political agendas.

14 For more information on this, see Yasemin Avcı, "Jerusalem and Jaffa in the Late Ottoman Period: The Concession-Hunting Struggle for Public Works Projects," in Late Ottoman Palestine: The Period of Young Turk Rule, ed. Yuval Ben-Bassat and Eyal Ginio (London: I. B. Tauris, 2011). See also Sotirios Dimitriadis' chapter on the Jerusalem tramway in the volume.

15 Rashid Khalidi, Palestinian Identity: The Construction of Modern National Consciousness (New York: Columbia University Press, 1997), 69, 77.

16 Moshe Sharet, Nitra'e ve-Ulay Lo: Mikhtavim me-ha-Tsava ha-'Otomani 1916-1918 [Shall we ever meet again? Letters of an Ottoman soldier 1916-1918], ed. Ya'akov Sharet (Tel Aviv: Ha-'Amuta le-Moshe Sharet, 1998), 158. 
In the months and years following the 1908 revolution, the Ottoman nonMuslim populations entered politics as equals alongside their Muslim counterparts for the first time since the foundation of the empire. This was evident in the reopening of the Ottoman parliament in 1908. The parliament was characterized by its diversity of religious and ethnic groups: Turk and Arab Muslims were the largest groups, joined by a number of Greeks, Armenians, and Jews. In the years following the 1908 revolution, this new sense of equality was cultivated in the nation's capital of Istanbul, but was also evident throughout different urban arenas within the Ottoman lands (Memālik-i 'Oșmāniye).

Whether it be in Istanbul or Jerusalem, the Young Turks' revolutionary slogan, "Liberty, Equality, Fraternity and Justice," ushered in a new era of civic nationalism, where, regardless of ethnicity or religion, citizens embraced the notion of Osmanlulik, or Ottomanism, an inclusive type of nationalism embracing all peoples of the Ottoman state. Once again, I turn to Campos, who states that following the revolution, a new dynamic of "civic Ottomanism" was introduced. She describes this dynamic as "a grassroots imperial citizenship project that promoted a unified sociopolitical identity of an Ottoman people struggling over the new rights and obligations of political membership."17 Similar cases can be found also within Ottoman Anatolia, where multireligious and multiethnic groups supporting the new spirit of the revolution were formed. Such groups included the Society of Patriots (Vatanperverler Cemiyeti), which was made up of Muslims, Greeks, Armenians, and Catholics. ${ }^{18}$ In the multiethnic and religious city of Izmir, one of the Jewish MPs, Nisim Matsliah, prided himself on the fact that he received the vote of both Jews and Muslims. ${ }^{19}$

\section{Ottoman Jerusalem: A Mixed City among Its Many Forms of Divisions}

In her focus on Ottoman Jerusalem, Jacobson argues that Jerusalem needs to be treated as a "mixed city." She stresses the importance of "integrating Jews and Arabs into one historical analysis ... [which] recognizes and investigates the differences between and within these two groups and their experiences, and examines the forces and dynamics that influenced them and the

\footnotetext{
17 Campos, Ottoman Brothers, 3.

18 Ohannes Kilicdagi, "The Bourgeois Transformation and Ottomanism Among Anatolian Armenians after the 1908 Revolution" (MA diss., Boğaziçi University, 2005), 68.

19 Ha-Olam, March 3, 1909, 13-14.
} 
dilemmas they faced at this time of transition." ${ }^{20}$ During the late Ottoman era, Jerusalem was made up of numerous religious, ethnic, and linguistic groups, with the three main divisions, Jews, Christians, and Muslims, forming along the Ottoman division of religion as regulated by the millet system. ${ }^{21}$ Despite the widely-held notion that the Old City of Jerusalem is divided into four clearly demarcated quarters, Jewish, Muslim, Christian, and Armenian, "the quadripartite division of Jerusalem ... is a relatively late cartographic invention plastered on Jerusalem by European observers."22 Vincent Lemire, in his book Jerusalem 190o, points out that before 1837, "cartographers did not assign any ethnic-religious categories to any given part of the city," and the appearance of such maps coincided with the opening of the European consulates in the late $1830 \mathrm{~s}$. He reminds readers that the "quadripartite division only became set from the 1860 s on."23 The intermixing of the communities is also verified in the 1905 Ottoman census, where we find large groups of Muslims living in the Jewish Quarter, and vice versa. ${ }^{24}$ It is for this reason that Lemire argues that we need to focus on other divisions within Jerusalem's societies, such as "between the rich and poor, between secular and religious, between artisans and intellectuals." We should extend these categories to relevant distinctions between residents of Jerusalem's walled city and its new neighborhoods, which, by 1900, made up over half the population. ${ }^{25}$

In his review of multiple population censuses and statistics, Roberto Mazza provides a coherent breakdown of the city, calculating that in 1914, a total of eighty thousand people inhabited Jerusalem. At fifty thousand, Jews were the largest group, while "Christians and Muslims were more or less equally divided," placing them at about fifteen thousand for each community. ${ }^{26}$ However, Jews and Arabs were not homogenous. Though Muslims were largely Sunni Arabs, this division also included small populations of North African and Indian Muslims, and Turkish officials based in the city. In addition, the largest group of Sunni Arabs were divided in terms of loyalties towards their notables and religious leaders. ${ }^{27}$ Likewise, the majority of Christians in Jerusalem were also Arab. The largest community, which made up seven thousand of the

\footnotetext{
20 Jacobson, From Empire to Empire, 2.

21 Roberto Mazza, Jerusalem: From the Ottomans to the British (London: I. B. Tauris, 2009), 34 .

22 Lemire, Jerusalem 19oo, 17.

23 Ibid., 26.

24 Ibid., 27.

25 Ibid., 20.

26 Mazza, From the Ottomans to the British, 39.

27 Ibid., 40.
} 
fifteen thousand overall total, were Greek Orthodox (the church hierarchy also included ethnic Greeks), and the Catholic community was also made up of a majority of Arabs (even if not at the same level as the Greek Orthodox), and numbered 4,500. ${ }^{28}$ During the late nineteenth and early twentieth centuries, Muslim and Christians started to unite under the banner of Arab nationalism, and following the 1908 revolution, together with the other regions in Palestine, they began to imagine themselves as a modern political community. Collectively, they identified with what I call Palestinianism, which was not an ethnic or separatist nationalist identity, but rather a local identity that developed within the context of a larger Arab identity. ${ }^{29}$

Jerusalem's Jewish community was made up of numerous ethnic and linguistic groups and was arguably even more divided than the city's Arab populations (Muslim and Christians). First, the fifty thousand strong Jewish community was split along the Ashkenazi-Sephardic divide, with the Ashkenazim tracing their origins back to eastern Europe and the Sephardim tracing their roots back to Spain, whose expulsion of the Jews in 1492 sent many to Ottoman cities such as Salonika, Edirne, Istanbul and Izmir, and to those in the Ottoman Arab heartlands, such as Damascus, Beirut and Jerusalem. However, within each of these two main categories, there were numerous subgroups. In fact, the late nineteenth century, the Yishuv was made up of immigrants from different parts of Eastern Europe, the Ottoman Arab lands, the Balkans and North Africa. Some spoke Yiddish and Russian, while others spoke Ladino and Arabic. Furthermore, there were other groups that did not trace their roots back to Ashkenazim or Sephardim at all, such as the Persian-speaking Jews of Bukhara and the Arabic-speaking Jews of Iraq and Yemen, to name a few. In addition, there were the Jewish families who could trace their roots back for generations in Palestine. As we will see below, these different communities started to unite under a local form of Zionism, which for the first time started to break down the main barrier dividing Ashkenazi and Sephardic Jews.

\section{The Limits of citadinité in the Post-19o8 Period}

During the last decade, the scholars working on Ottoman Palestine have placed great emphasis on documenting relations between the Jewish and Arab communities, specifically within the urban sphere of Jerusalem. In addition to the works mentioned in the introduction, other studies within this field look at cases of intercommunal microrelations within Jerusalem, such as the relations

28 Ibid., 43 .

29 Fishman, Claiming the Homeland. 
between the Jewish Ishaq Shami and Arabs ${ }^{30}$ and that of the Sephardic Valero family. ${ }^{31}$ There also is a recent documentary on the era entitled 1913: Seeds of Conflict, ${ }^{32}$ which combines the opinions of these scholars and works to recreate the world of Jawhariyyeh. This documentary, which was based on the book Jerusalem 1913: The Origins of the Arab-Israeli Conflict, recreates a world where Muslims, Christians and Jews lived together and interacted in the neighborhoods of the Holy City. ${ }^{33}$

These narratives, which have focused closely on Jewish-Arab relations, have been central to deconstructing the dominant narrative of conflict that emerged during the subsequent British Mandate, the founding of the Israeli state and the Palestinian Nakba, and the years of Israeli occupation of the West Bank and the Gaza Strip. In other words, by demonstrating that relations between the different communities existed, these works show us a period when the two peoples were not set in conflict but rather interacted with each other as Ottoman citizens within multiple communities.

Parallel to the emergence of this new narrative, some scholars, including myself, have started to question the extent of these relations. For example, Edhem Eldem, who focuses on Ottoman Istanbul, argues against understanding the mixing between the different communities as something widespread in Ottoman cities. He holds that it certainly did not expand to the bulk of the population. Eldem writes, "indeed, the quaint and endearing image of Greeks, Armenians, Muslims and Jews sharing space, business and entertainment tends to mask the very real fact that the overwhelming majority of the population, across the board, was in fact held at bay from this protected and restrictive environment." ${ }^{34}$ Lemire emphasizes that his work, which focuses to a great extent on the dynamics of citadinité, is not aimed at "painting an idyllic portrait of a peaceful city blessed with a web of respect and mutual consideration between its inhabitants. Jerusalem around 1900 was, like all urban societies, a

30 Salim Tamari, "Ishaq al-Shami and the Predicament of the Arab Jew in Palestine," Jerusalem Quarterly, no. 21 (2004).

31 Ruth Kark and Joseph B. Glass, "The Valero Family: Sephardi-Arab Relations in Ottoman and Mandatory Jerusalem," Jerusalem Quarterly, no. 21 (2004).

32 Ben Loeterman, 1913: Seeds of Conflict Trailer, April 8, 2015, accessed January 19, 2018, https://youtube/OlvTVvuI 30 E.

33 Marcus Amy Dockser, Jerusalem 1913: The Origins of the Arab-Israeli Conflict (New York: Viking, 2007).

34 Edhem Eldem, "Istanbul as a Cosmopolitan City: Myths and Realities," in A Companion to Diaspora and Transnationalism, ed. Ato Quayson and Girish Daswani (Chichester: Wiley Blackwell, 2013. 
place crisscrossed by conflicts, competition and power relations." ${ }^{35}$ However, he asserts that "conflicts did not yet happen along the fracture lines between communities that we see nowadays." ${ }^{36}$ Certainly, his work on Jerusalem's municipality reveals that perhaps Jerusalem should be seen as a unique case because it was the second city in the Ottoman Empire that, due largely to a local initiative, established a municipality in the mid-186os and was characterized by its Muslim, Christian, and Jewish representation. ${ }^{37}$ Furthermore, Lemire's differentiating between Jerusalem's old and new cities and the dynamics of relations between Jews and Arabs within these two realms provides us with an important key to understanding how relations developed differently at various points in time and space.

Eldem's claim that mixing between the communities of Istanbul was limited could hold a kernel of truth when applied to Jerusalem. Perhaps the interchange of relations was reserved mostly for municipality leaders and other probable classes who "embodied this urbanness in full flower." ${ }^{38}$ In fact, for now, the sources used to portray neighborly relations between Jews and Arabs only seem to scratch the surface, making it difficult to substantiate the claims of a widespread multicultural sense of citadinité. For example, a good part of the scholarship on neighborly relations in late Ottoman Jerusalem is based on Jawhariyyeh's memoirs. Until now, however, no scholar has scrutinized these memoirs as a source for explaining relations between the two communities. That Jawhariyyeh recorded his thoughts and impressions decades after events occurred could undermine the accuracy of his descriptions of the late Ottoman period. Furthermore, we need to recognize that he was born in 1897, making him an eleven year old child when the revolution occurred. Thus, for example, his claim that following the revolution, Arabs welcomed the coup but Jews in the city mocked it seems based solely on hearsay. It would indeed be hard to imagine an eleven-year-old retaining such detailed information. It also contradicts most primary sources, which state that the Jewish community, like the Arab one, welcomed the revolution. ${ }^{39}$ One of the editors of Jawhariyyeh's memoirs, Issam Nassar, who is a contributing member of this volume, recognizes their limitations as a source. According to Nassar, this is a "memoir written - and rewritten - after the

\footnotetext{
35 Lemire, Jerusalem 1900, 5 .

36 Ibid.

37 Ibid., 104.

38 Ibid., 112.

39 Salim Tamari and Issam Nassar, The Storyteller of Jerusalem: The Life and Times of Wasif Jawhariyyeh, 1904-1948 (Northampton: Olive Branch Press, 2014), 70.
} 
fact." He explains that the memoirs appear to be based on "notes and diaries that he had written earlier." Jawhariyyeh's narrative is unquestionably valuable as we have little material from the period that addresses daily life in Jerusalem. However, caution is required when citing the memoirs as an overarching source, even if they do appear to be in keeping with other emerging narratives. Another case in which the Jawhariyyeh memoirs fall short of providing the full picture is in his description of Jerusalem's holy days as being celebrated by all three religions. His descriptions are often vague and unchanging over time. For example, he recalls that the Jewish celebration of Purim took place alongside a Greek Orthodox carnival that coincided with the last day of Lent. According to Jawhariyyeh, Jews and Muslims gathered together with Christians to observe the procession of people dressed in costume. However, in his description of the Jewish holiday of Purim, he states "the carnival tradition was also acted out by the Jewish community of Jerusalem at their homes and in their communes." He goes on: "We spent long evenings among them in their communes marveling at what we saw, particularly at the time of the Ottomans." ${ }^{40}$ From this passage, we can learn that indeed, festivities did offer opportunities for the different religious groups to come into contact with one another. However, we learn nothing at all about his interactions with Jewish celebrators (or viceversa, concerning the Greek Orthodox procession). ${ }^{41}$ Further, we learn from Jawhariyyeh that the Jewish celebration of Purim was being celebrated in Jewish neighborhoods (he appears to stress "their" homes and "their" neighborhoods). In other words, this could point to the fact that even if there were Jews living together with Arabs, the public celebration of the Jewish holiday took place in areas demarcated as Jewish neighborhoods.

In a section where he writes on neighborly relations, Jawhariyyeh uses the aforementioned Greek Orthodox carnival as a point of reference for celebrations that Christians and Muslims from the same neighborhood celebrated together, with no mention of Jewish participation. ${ }^{42}$ Also, it is clear from the passage that he is writing this in retrospect. Compared to later eras, this may have been more common in the Ottoman era, but it is hard to extract more

40 Tamari and Nassar, The Storyteller of Jerusalem, 58. In his recollection of going to the Dusturiyye school, Jawahariyyeh describes also a school where both Muslims and Christians studied together. Here, there is also no mention of Jews studying with Arabs, 74-76.

41 There are also reports of Arabs taking part in Jewish celebration of Lag B'Omer in Safad during the late Ottoman era. See Ha-Herut, June 15, 1913, 3. 
information about the extent of the interactions. Were the different groups simply onlookers at each other's festivities, or did they use the moments as opportunities for social exchange? Crucial to understanding relations in the late Ottoman era is to see how they transformed as the local populations the Jews and the Palestinians - were thrown into conflict by the growth of Zionism and an increasing a sense of Palestinianism, which was not only a reaction to the rise of Jewish nationalism but was also part of their desire to protect the Holy Land from European imperialism.

Jawhariyyeh's descriptions of the shared space during the holidays bear striking resemblance to events in Ottoman Izmir. In her work on the port city, Sibel Zandi-Sayek explores relations between its different communities. Concerning holidays, she writes,

Although each community celebrated its own holy days, many observances were made known to all because of their implications for the daily life of the entire city. Businesses and shops owned by Muslims, Jews and Christians were closed on Fridays, Saturdays and Sundays, respectively, which pressed other groups to make their provisions accordingly and left only four workdays for the entire city. ${ }^{43}$

She goes on to explain that holy days also included "public feasts [which] transformed the physical spaces of the city and created a temporary reconfiguration of public life. On these occasions, people refashioned select streets and other outdoor spaces to house or otherwise mark these events." 44 Like in Jerusalem, the late Ottoman period in Izmir also reminds us that "feasts and ceremonies animate the history of Ottoman urban communities, which are too often portrayed in neatly delineated religious, ethnic, and national categories." ${ }^{25}$ Lastly, missing from Jawhariyyeh's narrative is the fact that "religious feasts also produce more spontaneous transformations of the city's spaces. Holy days could be provocative; fueling latent prejudices, reifying the social boundaries between the neighborhoods, and rendering visible the power inequalities among them." ${ }^{46}$ This certainly held true in Jerusalem, where during the spring season of Passover and Easter, tensions between the different communities

\footnotetext{
43 Zandi-Sayek, Ottoman Izmir, 154.

44 Ibid., 156.

45 Ibid., 186.

$46 \quad$ Ibid., 156.
} 
increased, whereas the city depicted in Jawhariyyeh's descriptions seem to be devoid of conflict between the different communities. ${ }^{47}$

\section{The Linguistic Question of the Sephardim}

A complex dimension of Jerusalem citadinité is that local Sephardic communities had stronger ties with Palestinians than the Ashkenazi Jews did due to the fact the former spoke Arabic. Some even claimed they shared a "common identity" as Arabs. In his abovementioned book on Jews and Arabs, Menachem Klein states: "Before nationalism brutally separated the two words 'Arab' and 'Jew' and required the inhabitants of Palestine to count themselves as one or the other, there were people who thought of themselves as Arab Jews" and explains that "Arab-Jewish identity and local patriotism emerged alongside a sense of belonging to the Ottoman Empire." While we know for certain that there were a small group of Arabic-speaking Jewish intellectuals in Palestine during the late Ottoman period who defined themselves as such, this claim seems exaggerated when speaking of the Sephardic Jewish community in Palestine as a whole. ${ }^{48} \mathrm{~A}$ large part of the Sephardim in Jerusalem most likely did not see themselves as "Arabs," but possessed a Sephardic Jewish identity, which was inherently connected with the other Ottoman Jews within the empire. ${ }^{49}$ Klein then brings us back to the discussion of mixed neighborhoods, quoting from the memoir of Ya'akov Yehoshu'a, who writes that "the residential courtyards of the Jews and Muslims were common. We were like one family, we were all friends. Our mothers poured out their hearts to Muslim women and they poured out their hearts to our mothers. The Muslim women accustomed themselves to speaking the Ladino language. They frequently

47 During the late Ottoman era, there are documented cases of conflict not just between Jews and Muslims and Christians and Jews, but also between Christians and Muslims. That Jawhariyyeh does not document this leads in part to a nostalgic cosmopolitanism which could very well fail to reflect reality.

48 Jacobson, From Empire to Empire, 82-166.

49 Despite Klein's exhaustive work, his argument that Jerusalem's Sephardic Jewish population identified as "Arabs" seems hard to substantiate. Furthermore, Klein's use of memoirs also is problematic to an extent; for example, he quotes Palestinian writer Ghada Karmi to strengthen the argument that Sephardim did consider themselves "Arab Jews" in the late Ottoman Empire. According to Karmi, "We knew they (Ashkenazi) were different from 'our Jews,' I mean Arab Jews." However, Karmi herself was only born in 1939, and the quote, which projects an Arab identity on the Sephardim, is from a memoir she wrote in 2002. 
used that language's proverbs and idioms." This recollection is in keeping with Campos' quote about Muslim women learning Ladino. In other words, these are examples where Jewish residents' knowledge of Arabic was not a foregone conclusion. We observe that Arabs (Muslims and perhaps Christians) did learn Ladino. Perhaps we should reexamine the claim that "closer relations between Sephardi Jews and Muslims can be put down to the fact that they shared a common language. ${ }^{50}$ While it would be erroneous to dismiss these relations, future research needs to look beyond the (perhaps constructed) nostalgia and expand on socioeconomic conditions that explain the essence of Jewish-Arab neighborhood relationships. This certainly could portray a unique form of citadinité that transcends explanations of ties based on language or political developments, providing an important counterweight to a great deal of the current literature. Other cases emerging in the late Ottoman period of Palestinians learning Hebrew in order to communicate with the Jewish community offer insight into the relations between the two groups. ${ }^{51}$ Of course, a more focused research on Arabs studying and speaking Jewish languages would also expand our understanding of citadinité, showing how the voluntary acquisition of a language to communicate with others broke down boundaries and created new social relations.

In my own research, I have uncovered different accounts that cast doubt on how widespread the phenomenon was of Jews (Sephardic or Ashkenazi) knowing Arabic. In a report prepared during the years before World War I, the Zionist official Arthur Ruppin supplies a breakdown of languages within three Hebrew kindergarten classes. Out of 305 children, Ruppin claims that only 7.1 percent spoke Arabic as their mother tongue; not surprisingly, and in sync with Ottoman Jewry as a whole, the largest language spoken among the Sephardic children was Ladino (39.3 percent) and then Yiddish ( 38 percent). Following Arabic, other notable languages were Bucharic Persian, Georgian, Moroccan dialect, and Bulgarian. ${ }^{52}$ While some might contest Ruppin's work due to the fact that he was a representative of the Zionist Office, this survey seems it may

5o Kark and Glass, "The Valero Family," 30.

51 Ha-Herut, October 20, 1912, 3. In this article, we see documentation that some Arabs were learning Hebrew in the Jewish settlement of Zikhron Yaakov. In a memoir of a trip to Palestine, one American Jewish visitor, Benjamin Lee Gordon, to Ottoman Palestine, comments that on the train to Jerusalem, the Arab conductor communicated with him in Yiddish. He then goes on to also mention Arabs learning Hebrew because it was to their "advantage." See Benjamin Lee Gordon, New Judea: Jewish Life in Modern Palestine and Egypt (Philadelphia: Greenstone, 1919), 107.

$5^{2}$ Arthur Ruppin, The Jews of To-Day, trans. Margery Bentwich (New York: Henry Holt, 1913), 262. 
have been carried out in order to learn about the different communities and gain an understanding of how to instill a sense of Zionism. There would thus be no reason to play down the number of Jews speaking Arabic. In fact, given the circumstances, the opposite could have been true.

In 1910, the question of how much Arabic the Jews knew was the subject of a discussion in Jerusalem's Sephardic Hebrew newspaper Ha-Herut. In a letter addressed to the Ottoman Jewish community of the northern city of Safad, education supervisor and leading notable Salah al-Din Hajji Yusuf questioned why Jews were not learning Arabic and explained that "unfortunately, there is not one Ottoman Jew in Safad who knows how to read or write, a little or a lot." He then goes on to explain that due to this, the government was forced to give a government position allotted for a Jew to a Christian. He then asks:

Why is it that you are lazy? When will you finally treat the learning of Arabic as an equal? This is the language of the land, and as Ottomans you have the right to participate in legal matters and the rest of the government's administrative tasks. You can only benefit from these rights if you know the language of the state and only then can you work for your homeland, and to benefit from it as your supreme councils do as a result of your knowledge of other languages. I especially direct this call to my friend Mr. David Yusuf Efendi [editor of Ha-Herut] ... who knows the Hebrew language well, that he alert his brothers and his fellow people to the urgency of this and to the great pleasure they will reap by knowing Arabic and to point to the benefit the Ottoman Jews will obtain by doing so ... I know the love this respected editor has for his land (artso) and homeland (moledeto) and his will for the development of the state (medina). I hope that he will help me with this Holy Work for the good of our homeland. ${ }^{53}$

Salah al-Din Hajji Yusuf was correct in his assessment that the editor of Ha-Herut was interested in advancing the study of Arabic and Turkish among the Jewish community. However, what quickly becomes clear is that the Ottoman Jews of Safad were not the only group being discussed. Rather, the overall Sephardic Jewish community in Palestine, including Jerusalem, was part of the analysis. In response to Yusuf's letter, the editor elaborates that his paper led the campaign to teach Arabic and Turkish in schools, yeshivas, batey midrash, and even the Talmud Torah networks. According to the editor, some schools had already adopted a rigorous Arabic program and a teacher had been 
sent to Istanbul to complete a language exam, enabling him to teach Turkish upon his return. After expressing the extreme loyalty Jews have towards their Ottoman homeland, he reiterated that:

once we raise a generation of boys loyal to their homeland, we can hope that through their national feelings and their love of the Land, and through their knowledge of Turkish and Arabic - the languages of the state - we will receive high positions in the administration and the leadership of the army; we will participate in all branches of the government that (are currently) taken care of by those Muslims and Christians who know these languages.

The information provided here suggests that a great number of the Sephardim did not know either of the two languages well. This should not come as a surprise, however, since for many Ottoman Sephardim, French had long since become their language of choice. Further, Hebrew was quickly being adopted as the main language of communication among the Jews of Palestine. Many Sephardic Jews must have spoken a basic level of Arabic. Even so, they still lacked the Arabic reading and writing skills needed to serve the country and to integrate into the workforce within the larger Arab population in Palestine. While it is not possible to go into further detail, the issue of how many Jews actually knew how to read and write in Arabic arose in a Ha-Herut debate, in which the need to establish an Arabic newspaper to counter the anti-Zionist rhetoric in the local Arab press was suggested. One commentator stated that only a handful of Jewish intellectuals could read or write Arabic. ${ }^{54}$

In light of this, the above case of Muslim women speaking Ladino makes even more sense. If Jewish women did not have a strong grasp on the Arabic language, it could be that it was actually their Arab counterparts who were learning Ladino in order to communicate with them. Noteworthy also was that many Ashkenazi immigrants realized the importance of learning languages early on. Once in Palestine, they often learned Turkish (and some Arabic), understanding the central role it played in promoting their goal of an autonomous Jewish land under Ottoman control.

What was not questioned in Hajji Yusuf's plea to learn Arabic was the fact that the Jewish community in Palestine - regardless of ethnic or linguistic background - had already adopted Hebrew as their main language of study, and it was quickly becoming the lingua franca of the Jewish Yishuv. The proliferation of Hebrew in Palestine took hold before the 1908 revolution

Ha-Herut, July 4, 1912. 
and gained momentum after it, developing into a type of local Ottoman Zionism that was not only found in Palestine but was prevalent throughout other Ottoman cities. According to Julia Phillips Cohen, "Proponents of the movement judged their interest in the renaissance of Jewish culture and the Hebrew language to be in line both with the national aspirations of other Ottoman millets and with the promise of the new constitutional regime more generally." And "they were also careful to articulate a vision in which Palestine would become a national center and place of refuge for persecuted Jews without becoming a separate state."55 For example, the Sephardic Jewish Ottoman MP Nisim Matsliah, who was originally from Salonika but ran for elections in Izmir, noted that "I side with the right of Eretz-Israel as a spiritual national center; such a national center will play without a doubt an important role in our national lives, and due to the fact that our spiritual homeland will not be possible without settlements, we will support the settlement of Jews in Eretz-Israel as much as possible. ${ }^{n 6}$

For Ottoman Jews in Palestine, which included a majority of Sephardic Jews, together with a smaller minority of Ashkenazi Jews, the revolution connected their future with the survival of the Ottoman state, even so far as joining the ranks of its military as patriotic Zionists. For these young people, who were born and bred on a synthesis of local Zionist ideology and Ottoman patriotism, there was no contradiction between supporting the Ottoman state and settling the Land of Israel. However, this led to greater divisions in Palestine. For the actors of the revolution, the future was bound to Istanbul, but this notion was not shared by the overwhelming majority of Palestinians on the ground. The process of connecting directly to Istanbul was in keeping with changes occurring among Greeks and Armenians of the empire, where a national revival of a language and culture would be integrated with the new emerged civic Ottomanism, also in essence tying them closer to the capital through their representatives in the Ottoman parliament. These ethnic religious groups encouraged an Ottoman patriotic agenda in order to receive linguistic and national rights, leading to a certain level of separatism. Many Jews who adopted an antiZionist stance nevertheless supported Jewish migration to Palestine. This was the case of the influential Ottoman chief rabbi Hayim Nahum, who also lobbied on behalf of the Jewish Yishuv in Istanbul, which exhibited the centrality of Istanbul in the everyday lives of Jews in Palestine.

55 Julia Phillips Cohen, Becoming Ottomans: Sephardi Jews and Imperial Citizenship in the Modern Era (Oxford: Oxford University Press, 2014), 104.

$5^{6}$ Ha-Olam, March 3, 1909, 13-14. 


\section{Ottoman National Politics and Renegotiating the millet System}

On the political front, Bedross Der Matossian criticizes historical descriptions of a post-1908 utopian sense of equality between different ethnic groups within the empire, stating that "romanticizing the period and arguing that the different ethno-religious groups within the empire tried to see themselves as part of an Ottoman nation under the label 'civic nationalism' is rather misleading." He goes on to state that "constitutionalism failed to create a new understanding of Ottoman citizenship, grant equal rights to all citizens, bring under one roof in a legislative assembly, and finally resuscitate Ottomanism from the ashes of the Hamidian regime. ${ }^{57}$

Adding to this, I argue that the introduction of the new multireligious and multiethnic parliament introduced a period in which each community was "renegotiating the millet system," drawing new boundaries and reaching new understandings of what these changes really meant in practical terms. In short, even if the streets of Istanbul, Thessaloniki, or, for our purposes, Jerusalem, could be described as places of intercommunal relations exhibiting multiple forms of citadinité, the transformation from the millet into "national communities" led to a strengthening of divisions that begun to be broken down in the late nineteenth century. ${ }^{58}$ Furthermore, while it would be difficult to argue that a "civic Ottomanism" did not exist, the communities clearly remained divided, whether in the provinces or the urban areas, with each non-Muslim community separately voicing their grievances with respect to the Muslim political elite of Istanbul. In other words, even in the midst of this "civic Ottomanism" there remained a hierarchy whereby non-Muslim communities had to convince the secular Muslim political elite that their wishes were not detrimental to the empire. Simply put, the millet system transformed into a new system in

57 Bedross Der Matossian, Shattered Dreams of Reality: From Liberty to Violence in the Late Ottoman Empire (Stanford: Stanford University Press, 2014), 2-3. In another article, Eldem explains the extent of mixing between the different religious groups among the professional class of Istanbul. See Edhem Eldem, "(A Quest for) the Bourgeoisie of Istanbul: Identities, Roles and Conflicts," in Urban Governance Under the Ottomans: Between Cosmopolitanism and Conflict, ed. Urlike Freitag and Nora Lafi (London: Routledge, 2014).

$5^{8}$ A similar case of appropriating one's current understanding of intercommunal relations onto the past can be found in Mark R. Cohen's analysis of al-Andalus, who claims that portrayals of the Islamic Middle Age has been misrepresented and that the "interfaith utopia was to a certain extent a myth." See Mark R. Cohen, "The 'Golden Age' of JewishMuslim Relations: Myth and Reality," in A History of Jewish-Muslim Relations: From the Origins to the Present Day, ed. Abdelwahab Meddeb and Benjamin Stora, trans. Jean Marie Todd and Michael B. Smith (Princeton: Princeton University Press, 2013), 28. 
which each community would begin to negotiate their demands from the new Muslim bureaucratic metropolis.

This remained particularly true in the case of Palestine; however, in this case it was Jews and Muslims vying for support among Istanbul's new secular Muslim elite, with each group setting its claims in opposition to the other's. As opposed to the previous system, preferential status of Muslims was replaced with equality before the law, and they were placed on an equal status with the Jewish community: a development which undermined Muslim hegemony. As this occurred, Muslims strengthened their ties with the Christian community, a bond that had already begun to be forged in the late nineteenth century with the rise of Arab nationalism. Jewish immigration continued and included Sephardic Jews - not just Ashkenazim - and the rise of Zionism within Palestine's local Jewish communities; Palestine's Arab population began to jointly identify themselves as "Palestinians" Filasținiyuun, with terms such as al-Sha'b al-Filasțini (the Palestinian people) becoming more common. ${ }^{59}$ This included the adoption of the peasant cause by urban Arabs (notables and a new emerging intelligentsia) in Jaffa, Haifa, and Jerusalem, separating Palestine's urban community from its counterparts in cities such as Damascus and Beirut. In other words, while Palestine's urban elite had strong ties with Syria, their sense of Palestinianism set them apart from their brethren there. Being Palestinian did not contradict their sense of belonging to the Arab people of the empire, nor did it bring into question their loyalty to the Ottoman state.

Even if relations between Jews and Arabs existed in the local urban arena, they never developed in the countryside, where Jewish and Arab communities remained separated. Unlike the Arabs, who adopted the peasant cause and created a sense of Palestinianism, the Jewish community never made attempts to create alliances with Arab peasants. My research shows that often the opposite held true. The Ottoman period bears a striking resemblance to the years of the British Mandate, and in some ways to Israel's postmandate relations with its Palestinian minority; that is to say, the Jewish Yishuv during the late Ottoman period was a self-segregated community and had little interest in or interaction with the Palestinian majority. Similar to these later periods, much of the time the Jewish community viewed the Arab through a narrow lens that focused on violence and mistrust. In the newspaper Ha-Herut, many articles report on random acts of violence and theft committed by Arabs against Jews. In these 
articles, one can detect a clear sense that Arabs were seen as the "other," and Jews killed by Arabs are often described as "martyrs."60

It is in this context that I argue that neither the Palestinian nor the Jewish community was able to contrive a sense of a mutual homeland. If there was any "uniting" or "imagining as a community," it was a process happening to each group separately and not involving the other. The transformation of the Jewish population into a national community was not a uniquely Ashkenazi phenomenon, but was equally strong among the Sephardim. Despite good relations between Arabs and Jews within certain neighborhoods, and despite participation in joint government ceremonies, which can be interpreted as concrete example of citadinité, both communities were being coopted into new national groupings. Each group looked independently towards Istanbul as the metropolis and there was no shared, horizontal sense of equality and brotherhood.

6o One needs only to skim the paper to come across numerous stories of Arabs attacking Jews and Jews becoming the victim of Arab violence. This point is central in understanding that similar to Ashkenazi Jews (who have been documented as "looking down" on the Sephardim, see Lemire, Jerusalem 19oo, 145-46), the Sephardic population also held prejudices towards the greater Arab population. It also can be argued that Ottoman Turkish administrators also held similar prejudices towards the Arab peasant and rural populations. 